\section{GENRE}

en séries
Genre en séries

Cinéma, télévision, médias

$6 \mid 2017$

Être mère, être père : représentations et discours médiatiques

\title{
'Why do I hate all the female characters in 24?' An etiology of 24's misogyny
}

\section{Alexis Pichard}

\section{(2) OpenEdition \\ Journals}

Electronic version

URL: http://journals.openedition.org/ges/994

DOI: $10.4000 /$ ges.994

ISSN: 2431-6563

\section{Publisher}

Presses universitaires de Bordeaux

Electronic reference

Alexis Pichard, "'Why do I hate all the female characters in 24?' An etiology of 24's misogyny", Genre en séries [Online], 6 | 2017, Online since 01 November 2017, connection on 18 February 2021. URL: http:// journals.openedition.org/ges/994 ; DOI: https://doi.org/10.4000/ges.994

This text was automatically generated on 18 February 2021.

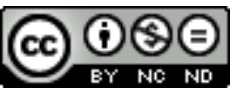

La revue Genre en séries est mise à disposition selon les termes de la Licence Creative Commons Attribution - Pas d'Utilisation Commerciale - Pas de Modification 4.0 International. 


\title{
'Why do I hate all the female characters in 24?' An etiology of 24's misogyny
}

\author{
Alexis Pichard
}

1 'I want her to die', 'lame, lame, lame', 'the weakest, stupidest (...) female character in the history of television', all these disparaging comments can be easily found online when searching for public reactions to the female characters of the American TV series 24 (Fox, 2001-14) ${ }^{1}$.The latter revolves around the diehard federal agent Jack Bauer and his efforts to prevent terrorist threats against the United States. 24 remains one of the most popular series of the 2000s as it was visually and narratively groundbreaking and captured the zeitgeist of post-9/11 America and the culture of fear that President Bush's War on Terror engendered.

2 In this light, 24 does not seem to target a female audience as it displays a maledominated world of action, violence and terrorism, which may account for its particular vision of women who are generally ascribed to secondary - most often negative - roles. Jack Bauer's daughter Kim for instance, has widely been panned by the critics, and the public as well, who have called her a time-consuming character with no common sense (McCabe, 2007 : 152) debasing 'any believability that the show has' (Brew, 2009). This article seeks to query the politics of representation in 24 and see where its misogynist discourse stems from.

3 First I examine and discuss the different female-character archetypes within 24 which heavily recycle traditional literary archetypes like the innocent damsel in distress, the evil seductress and the mad woman. I present three hypotheses which may account for the show's stereotyping of women. The fact that the series targets a male audience is one explanation but other contextual factors need to be explored. Lastly, I look at the late seasons of 24 to show that they arguably offer more philogynist representations and allow us to reevaluate the series on the whole. 


\section{Inducing misogynist reception: A study of 24's female characters}

4 The misogynist reactions that accompanied the series over the years were mostly fuelled by its rather negative representations of women which Janet McCabe has categorised into three archetypes: the 'narrative distracters', the 'narrative enablers' and the 'Lady Macbeth lookalikes' (2007: 149-161). This part explores and assesses this taxonomy which I intend to complete with a fourth archetype: the 'insane female characters'.

5 The 'narrative distracters' comprise the damsel in distress which is usually enacted by women in the show. McCabe uses the interesting term of 'distracters' because those female characters tend to distract CTU or/and Jack's attention "at a time when they are striving to thwart assassins and terrorist action" (2007: 152). As they distract everybody from trying to save America, 'narrative distracters' postpone the closure of the overall, most-important narrative. This is probably why viewers hate them so much : they generate frustration. In the first seasons, Teri and Kim Bauer repeatedly find themselves in life-threatening situations, therefore forcing Jack to intervene in order to save them. Although McCabe interprets these captive and rescue sub plots as empowering women for it allows them to exert control over the overall male narrative, she also acknowledges that the distractions in question offer a poor image of women in constant need of male attention and action. I think this is one feature that indicates the series' misogyny. The quality of the minor stories involving women never compares to that of the main more man-oriented plot, which tends to place viewers in a state of defiance towards female characters. As soon as they are on their own, we know that women will end up in a quagmire which will require male assistance. Simon Brew contends with much irony that had Kim Bauer got on a plane, 'it'd no doubt have turned out to be Oceanic flight 815' (Brew, 2009), a reference to the plane that crashed in TV series Lost (ABC, 2004-2010) and led the survivors to live on a mysterious, hostile island. In season 1, she is kidnapped at least three times, not to mention a car crash, an arrest for drug dealing, her mother's amnesia, rape and death in the last episode.

Season 2 goes even further, indulging in a dramatic overkill which provoked unexpected public reactions as it started seeing Kim Bauer as "a figure of ridicule" (Brew, 2009). If we subscribe to Brew's interpretation, we may contend that those 'narrative distracters' can also be 'narrative distractions'. The damsels in distress of 24 may also bring about some entertaining moments of 'comic relief', assuaging the overall tension of the story. Kim and her kin have a comic role to play within the show, although involuntarily, and this can be best seen in one episode in season 2 [S02xE11] which came to be called 'the Cougar Episode'. In an article entitled 'Kim vs. the Cougar. The Oral History of 24's Most Infamous Scene' (Lorre, 2013) Rose Maura Lorre retells the story of the episode during which fugitive Kim is lost in the Los Angeles Crest National Forest. After she gets trapped in a snare, she is menaced by a cougar appearing in the distance. Lorre remarks that the scene 'served as a lightning rod for viewers' longsimmering resentment toward the perpetually imperiled Bauer'. The infamous 'Cougar Episode' acted as a perfect distraction in a season filled with climactic and tragic moments (the death of CTU director George Mason, the explosion of the nuclear warhead in the Mojave desert, the impending war with the Middle East to name just a few) while emphasising all the more Kim's stupidity. 
7 The second archetype that is defined by McCabe is the 'narrative enablers', that is to say, women who act as helpers to the male hero(es). This category mostly comprises the CTU agents and analysts working with/for Jack such as Chloe O'Brian, Michelle Dessler, Erin Driscoll, Nadia Yassir (season 6) and agents from other agencies like Karen Hayes (season 5-6). At first glance, those female characters give a better image of women than the 'narrative distracters' since they are included in the main manoriented plot and work actively alongside the male heroes of the show in order to deter the terrorist attacks of the day. These women are usually strong, independent and excel at what they do. Chloe proves on many occasions that she is the best analyst of all agencies, acting as a priestess of computer sciences as she understands better than anyone else the electronic language of encrypted files, drones and satellites. Despite these working skills, Chloe is mostly portrayed as a socially challenged, autistic geek deprived of femininity. Until later seasons, she remains an asexual female character serving only as a 'male-performing woman'. McCabe argues that those 'narrative enablers' are the best at what they do because they manifest "unquestioned loyalty and [unwavering] obedience to the male hero (more than the organisation) " (2007: 156). It is because they obey and trust Jack - whom we know to be always right about everything - and are prepared to face charges for insubordination or treason that these women are heroic figures. Their heroic status depends on Jack. And when they choose to listen to him, they are never arrested or, if they are, never for long (see Chloe who was never shut out despite innumerable violations in procedure). Contrariwise as soon as they do not comply with Jack's exhortations (or that of other trustworthy male protagonists), women in 24 become 'narrative distracters' as their usually misandrist use of power entails dire consequences. Had Erin Driscoll (season 4) listened to Jack in the first place, CTU would probably have defeated Habib Marwan's organisation much sooner. McCabe notes that "when Erin Driscoll is summarily removed as CTU director it is in part as cultural retribution for failing to take proper care of her schizophrenic daughter [...] but also in part [...] as textual reckoning for dismissing Bauer over that small matter concerning his heroin addiction" (2007: 155). The idea of retribution is quite compelling in the series and implies that male characters know best and disobeying them can only lead to national and personal disasters. As soon as they try to get out of this chauvinist containment, these women's lives are in danger.

8 Another point that is worth mentioning is the attitude of women at work which also participates in their being resented by the public. First, they are usually solitary and do not share a team spirit (see Chloe whom Tony calls 'weird' [S03xE01]). Working women in the show often indulge in competitiveness with their female coworkers: there is no sense of female solidarity as they fight hard to be taken seriously by their male supervisors (see Carrie vs. Michelle in season 2, Sarah Gavin vs. Marianne in season 4, Chloe vs. Janis Gold in season 7). They do not hesitate to backbite and to report any suspicious activity of their female colleagues to their superiors. Second, working women are also often distracted by their personal lives. Sometimes they share a common past, usually the source of present hostility between them. In season 2, we learn that the new CTU analyst Carrie Turner was Michelle's former boss and that she had a devastating relationship with Michelle's brother Danny that led him to a suicide attempt. So from the start, they hate each other, and this will serve as one of the minor stories of the season, Carrie repeatedly attacking Michelle on her lack of legitimacy and denouncing her when she discovers that she illegally helps Jack. Third, most working women in 24 have vested interests, secret ambitions that make them untrustworthy 
characters. It is not coincidental that they are usually suspected of being complicit with terrorists, and therefore tortured (see Sarah Gavin, Audrey Raynes and Nadia Yassir), when they are not actual moles. Tellingly, female characters stand for almost a hundred percent of the total CTU moles.

Betrayal and treason are at the heart of McCabe's final archetype: Lady Macbeth, known for her deadly ambitions and evil plots throughout Shakespeare's play and her particular ability to manipulate her husband. In light of this short description, Sherry Palmer stands out as a contemporary African-American Lady Macbeth as she constantly contrives the most complex, cruel plans to serve her best interests and, sometimes, her husband's. Besides, like Lady Macbeth, Sherry is a powerful woman whose ambitions will lead to her downfall. Other characters of this kind include Nina Myers, Marianne Taylor, and Dana Walsh (season 8) : women who are driven by hubristic ambitions and intent to do whatever it takes to wield power. They are often seductive women who sexually use the male heroes to carry out their missions (Nina was Jack's mistress, Dana was engaged to Cole Ortiz, Marianne had a relationship with Curtis Manning) before betraying them and the United States as well as the viewers. Again, McCabe sees this thwarting of the viewers' expectations as empowering women in the show since they are "betrayer[s] of 24 narrative" and that "if 'trust no one' is the central premise, then these women are responsible for shaking our confidence" (2007:158). They cause some unpredictable twists and plots which allow them to dominate the narrative. One conclusion to such a representation is that women with ambition, intelligence and power rarely serve the greater good but often work with the enemy. The show makes it clear that, like Lady Macbeth, these evil women have no other future than death. So, although these women appear to be powerful, their quest for more power is consistently assimilated with a maleficent transgression and needs to be repressed by male authority.

Although McCabe's typology is perceptive and, on the whole, quite compelling, it leaves out one striking category that transcends all the others and which concerns the insane female characters in the show. True, male terrorists often prove to be insane in their own way; their motivations may not be rational, their religious fanaticism may seem delusional alongside their desire to kill thousands of people. Still, only female characters manifest physical signs of madness - mostly hysteria -, which participates in their being mistrusted by the viewers and echoes the conservative idea that insanity is a 'female malady', to quote Elaine Showalter's influential book on women and madness in $19^{\text {th }}-20^{\text {th }}$-century England (Showalter, 1987). Showalter demonstrates that madness was a cultural construction by male psychiatrists who linked it to femininity and female unrest, in other words, women who did not have an appropriate behaviour, thereby affecting the treatment of female mental health problems.

11 This blatant display of deep-rooted misogyny that was progressively contested and deconstructed throughout the twentieth century by waves of feminist thinkers is reasserted in 24. The first case of female insanity appears in season 2 with Marie Warner, a blond white girl who is about to get married with Reza Naiyeer when a nuclear threat is revealed. Soon, much to the viewers' astonishment, Marie, the archetype of the sweet American girl born and raised in a rich WASP family, turns out to be a sociopath working for the Islamic terrorist group Second Wave. After being exposed, she kills her fiancé alongside CTU agents to serve her cause and does everything possible to allow the nuclear device to go off in Los Angeles, eventually 
threatening to kill her own sister before Jack shoots her. Other insane female characters include Erin Driscoll's schizophrenic daughter Maya who is mostly portrayed in violent crises, struggling and screaming in the CTU medical clinic until she commits suicide. In season 5, the show introduces a more complex insane woman, Martha Logan, President Logan's wife. She is depicted in a Victorian fashion as her story shares some features with famous $19^{\text {th }}$-century novels such as Jane Eyre by Charlotte Brontë, which focused on female insanity and their consequent containment. She seems to be an avatar of Bertha Mason, commonly known as "the mad woman in the attic" (Gilbert, Gubar, 1979) - the echo being reinforced by the phonic similarities between the names Bertha and Martha. Martha suffers from depression and we know that, prior to the events occurring in season 5 , she was committed to a mental institution. Her mental instability is emphasised as early as her first appearance since after dressing up and being made up, she looks at herself in the mirror (another key object in Victorian novels) and dunks her head into water as she is unsatisfied with her assistant's work [S05XE01]. From the start, the viewers are asked to distrust Martha because of her erratic behaviour which makes it necessary for her to be contained.

Although female insanity is at times the product of men's manipulations - for example Martha is played by her husband because she knows about his involvement in the assassination of former President David Palmer - the show suggests that madness remains intrinsic to women.

\section{A multi-factorial reading of 24's misogyny}

Several factors can explain these rather negative representations of women. Firstly, many critics have argued that they are linked to the generic hybridity of 24 which brings together two main genres : the action-adventure series and the soap opera. The male-dominated action-adventure series, Joke Hermes explains, is a motley genre incorporating features from "the crime series, the detective or spy series, and the TV thriller" (2007: 164) and as such it mostly targets a male audience. Hermes also sees 24 as an espionage series of the sixties transferred into our postfeminist era, pointing to the fact that Jack usually works for women but because they make the wrong decisions, " [he] still commands the field of action" (2007: 165). The show is also influenced by the action-hero films of the nineties, most notably the Die Hard series portraying John McClane in impossible situations, although Hermes aptly remarks that the cynical tone of these films is not to be found in 24 where the gravity of the plot seldom gives way to comedy (2007: 166). As for the soap opera, the genre can be defined as telling the excessively eventful lives of one or several families in a narrow narrative and visual diegetic world. Soap operas are broadcast every day and target a female audience. Because of the generic experimentations of TV shows in the early eighties, the traditional dichotomy between nighttime action-adventure series - also called cop shows - and daytime soap operas progressively disappeared so that every series started to incorporate elements from both genres (McPherson, $2007: 175) .24$ is representative of this trend.

In soap operas, the portrayal of women is largely stereotypical and serves to promote traditional gender roles. Submissive, sweet-natured and sacrificing women are presented as 'good' whereas independent, rebellious women are usually characterised as 'villainesses' (Mumford, 1995). These 'bad' women are strong, wealthy matriarchs 
who spend their time defying male authority by having love affairs, hiding the real paternity of their children or getting a divorce, and plotting against their female rivals. Mumford notes that although these 'active villainesses' seem to depart from the traditional representation of women as passive characters, the soap opera's patriarchal ideology always prevails in the end and "undermine[s] whatever progressive or woman-centred message we might see in 'evil' women shaping the circumstances of their lives" (Mumford, $1995: 112$ ).

So, even though 24's deployment of soapy content may appear surprising for a show targeting a male audience as soap opera is usually considered a 'feminine' genre, it is somehow consistent with the misogynist ideology at work since soap operas are strewn with conservative depictions of both femininity and masculinity. Therefore, the soapy elements help 24 secure its attempt at restoring male authority and agency in post-9/11 years. It should also be noted that the series does not merely recycle soap opera tropes and characterization, which would tend to 'feminise' the narrative at the risk of alienating a part of the male audience. As McPherson deftly argues, 24 deploys hypertechnologized formal strategies (i.e. the 'masculine' videographic style which the split screen device epitomizes) as an "overcompensation for its abduction of what has long been seen as a highly feminised form" (McPherson, 2007: 176). Put differently, elements of the soap opera are contained within a 'masculine' narrative and aesthetic formula: their presence does not debase the show's endeavour to remasculinise the American hero and, beyond, America.

16 Secondly, 24 was broadcast on the conservative network Fox whose target audience is mostly young men (Guthrie, Rose, 2011), which may explain why the production of the show was dominated by male writers and directors. The writing of the original series seasons 1 to 8 - involved a crew of thirty-four writers with only a small core remaining from beginning to end. Out of these thirty-four writers, only five were women. Tellingly, in terms of episodes, only seven episodes out of the one hundred ninety-two episodes composing the original series were written by female writers. Having more female writers may or may not have dramatically changed the show but it could have influenced the way women were portrayed. Moreover, most of the writers of 24 were conservatives - the remaining being independents or leftists who worked under the supervision of Republican supporter Joel Surnow, 24's creator and showrunner for over five years. New Yorker journalist Jane Mayer showed in her influential article investigating the politics of the series that Surnow had close relationships with the Bush administration and that he shared their ideas on torture and the War of Terror (Mayer, 2007). For David Nevins, who was a Fox network official and who bought the series in 2000, there was no doubt that "Joel's politics suffuse the whole show" (Mayer, 2007). Arguably, torture was not the only issue on which Surnow agreed with the President for the representations of women in 24 also seem to pertain to the ideology which underlay the conservative agenda the Bush administration tried to implement between 2001 and 2009.

Indeed, although George W. Bush claimed during his 2004 campaign that 'W stands for Women', the policy he conducted as President regarding women's rights belied all his previous engagements. Barbara Finlay argues that "[he] and his administration have clearly set back the clock on women's progress, [...] work[ing] against many of the gains women had made over the past three decades, along with pushing back on civil rights advances in general" (Finlay, 2006: 4-5). Most notably, under the influence of the 
Christian Right and the Neoconservatives, the Bush administration promoted a fairly antifeminist social agenda aiming to "reestablish traditional gender roles and restore the patriarchal family as the hegemony family form in America" (Snyder, $2007: 19$ ). Thus, Finlay states that Bush declared war on women from the day of his inauguration onwards (Finlay, 2006: 9). This "War on Women' became more overtly aggressive after 9/11. Because of the threat of new terrorist attacks, the American society embraced militarism, which meant reestablishing masculine values and dominance and 'devaluing attributes traditionally associated with women" (Amnesty International, 2004: 2). The Bush administration developed a gendered rhetoric aiming at downplaying any opposition to its harsh policies : those who worried about due process and feared the War on Terror might durably impair people's constitutional rights were called 'hysterics' or 'feminine'. On the economic front, the War on Terror enabled President Bush to push his conservative agenda even further as increasing the military and homeland security provided the excuse to slash spending in social programmes that directly benefited women.

In The Terror Dream, Susan Faludi explores the American people's psychological response to $9 / 11$ in the ensuing days, weeks and years (Faludi, 2007). Faludi posits that during this period of coping, the Americans tried to repair the broken myth of invincibility by starting a process of remasculinisation which hinged on the return to a more traditional, gendered society. Firstly, women were asked to return to matrimony in order to restore "the illusion of a mythic America where women needed men's protection and men succeeded in providing it" (Faludi, $2007: 118$ ). At the same time, the Western imagery shaped by the Bush administration and the media turned women into vulnerable maidens who needed male protection from Islamic terrorists who, the President said, "were determined to bring death and suffering into our homes" (Faludi, 2007 : 5). Secondly, women were seen as partly responsible for the emasculation that the US had suffered. Feminists were publicly called traitors as "women's liberation had 'feminized' our men and, in so doing, left the nation vulnerable to attack" (Faludi, 2007 : 23). Therefore, many liberal journalists, thinkers, politicians and activists condemned what they saw as the 'War on Women' that the Bush administration was deliberately waging and which aimed at undermining women's reproductive freedom while rekindling sexism (Cupp, Joshpe, 2008). This collective 'terror dream', Faludi argues, lasted until the mid-2000s and had dire effects on women and feminism. Because it mirrors the social representations of women which developed after 9/11 under the aegis of the Bush administration, 24 can be interpreted as a sign of this general backlash against women, which makes it fairly representative of the period it was produced in.

19 The conservative views that rose in the aftermath of $9 / 11$ soon permeated most Hollywood productions. Senior Advisor Karl Rove facilitated the relations between the White House and Hollywood when, in November 2001, he organised a meeting with Hollywood executives, network representatives and other influential screenwriters and directors to "enlist their support" (Takacs, $2012: 10-11$ ). The media industry was thus asked to help support the war effort and adhere to the Bush administration's official patriotic line, which entailed framing the onscreen representation of the War on Terror. Even though the government did not force Hollywood to make propaganda and to 'punish' women, the fact that numerous war films (Black Hawk Down, We Were Soldiers, etc.) and TV series (Threat Matrix, The Grid, etc.) enjoyed "considerable assistance from the Pentagon in exchange for script changes to ensure favourable 
representation of the military [was] a clear indication of the political alignment of [these productions] " (Westwell, 2014:9). All in all, these films and TV shows affirmed and reinforced the dominant patriarchal discourse of the War on Terror. They notably staged captivity narratives, a literary genre which goes back to the foundation of the United States and in which a white, innocent American woman is abducted and raped by Native Americans before being rescued and avenged by a (white) American man. These captivity tales became central to George W. Bush's discourse after 2001 as they were part of a global attempt to restore American masculinity through force. It was fairly blatant in 2003 during the 'rescue' of US soldier Private Jessica Lynch, a 20-yearold white girl who had been injured - and supposedly held prisoner - in Iraq.

Westwell remarks that captivity narratives and rape-revenge films became prominent in post-9/11 films that portrayed common American men becoming heroes ${ }^{2}$. Those films were about imperilled children, usually white, blonde little girls who were kidnapped, sometimes raped, "resulting in an American man seeking bloody revenge" (Westwell, 2014: 52). Westwell argues that these little girls served as symbols "of an imperilled US in a dangerous and threatening world" (2014:52).

Despite the fact that 24 entered production months before the $9 / 11$ attacks and that other less popular series such as The Unit (CBS, 2006-10) were even more in tune with the Bush administration, it was regarded as "the most well-known [series] for touting the 'war on terror' line" (Brady, $2012: 112$ ). It unfolds similar captivity narratives again and again particularly in its first seasons. In season 1, Jack's wife and daughter are abducted and he has to go through impossible choices and actions in order to save them. This ordeal allows him to reaffirm his masculinity and paternity (which is challenged at the beginning of the show) and become the prototype of the post-9/11 American hero. Hermes calls Jack an "urban cowboy" (2007:165), who does whatever it takes to save his beloved, innocent family and his nation. After the 2001 terrorist attacks, the cowboy archetype, which taps into the collective fantasy of the wild frontier hero of the $19^{\text {th }}$ century, was largely used by the media to depict the overnight transformation of George W. Bush from a goofy president into 'a fighting machine' (Fineman, 2001). Bush was portrayed as a cowboy sheriff poised to do everything deemed necessary to avenge America and defeat the lawless jihadists (Dodwell, 2004). Such a depiction tended to reaffirm the President's (virile) power and remasculinise America by restoring patriarchal power. Bush himself endorsed the frontiersman archetype of the western imagery: he was often seen wearing a cowboy hat and stated "that the terrorist 'evildoers' were wanted 'dead or alive' and that al-Qaeda would be "smoked out" of their caves in Afghanistan" (Westwell : 2014, 51).

The captivity narratives that 24 unfolds thus aim at continuously reaffirming Jack's and the US' - virility and physical superiority to the detriment of weak, endangered women. In this Western-like plot that defined the psychological response to $9 / 11$, women need to suffer and die for the male hero to rise. This may be why most of the women Jack is romantically engaged with are raped, tortured and sacrificed, from his wife Teri to Renee (season 8) and Audrey (season 9).

By and large, 24's misogyny originates from three main sources that are all but separate. Firstly, the choice of two genres which traditionally offer very few positive female characters, namely the action-adventure film and the soap opera; secondly, the fact that 24 was a male-dominated production airing on a conservative network; thirdly, the post-9/11 political and social context as the Bush administration conjured 
up and rekindled strongly conservative views of women in order to repair America's broken masculinity. Still, as 24 aired for over a decade, it outlived the Bush presidency and continued its run into the Obama presidency. The last part of this article will thus discuss the possible evolutions of the series in its seasons taking place after the 2008 presidential elections.

\section{Women in the 'liberal-leaning' seasons: A switch to philogyny?} vision of gender representations at work in the show. These seasons may be labeled 'liberal-leaning' as opposed to the more conservative-oriented previous seasons because they display strong debates over the use of torture and consistently question the War on Terror and the PATRIOT Act along with the consequences of American imperialism. This palpable switch of politics is imputable to internal changes within the series' production since Republican Joel Surnow left the show at the beginning of season 7, opening a new political space for left-leaning executive producers and writers Howard Gordon (who had already been 24's showrunner since season 5) and Alex Gansa (Mayer, 2007). Other reasons that convinced the series' producers to slightly revamp it included Jane Mayer's article which stained 24's' image and inflamed the media into condemning the show's depiction and justification of torture, the steadily dwindling ratings of season 6 and the mixed reception of that season (Pichard, 2016). The ideological reorientation of the show was also influenced by external changes as the US political context itself changed a great deal. After eight years of Republican presidency which ended in massive popular discontent (Pickup, 2010), Democratic candidate Barack Obama was elected President in 2008. The newly elected president, who was the first African-American president ever, pledged that his administration would break with the heritage of the Bush years, and that he would 'regain America's moral stature in the world' (Obama, 2009) after a decade of unilateral preemptive wars overseas (Afghanistan and Iraq), trampling of civil liberties and crimes committed in the name of the victims of $9 / 11$.

As for women, Obama advocated more equality and consideration and seemed to put an end to the conservatives' 'War on Women'. In his book, The Audacity of Hope, Thoughts on Reclaiming the American Dream published in 2006, Obama praised single mothers (2006: $333)$, working mothers $(2006: 337)$ and lambasted the conservative vision of women as innate housewives: "Where social conservatives have been wrong is in insisting that this traditional role (author's note: what Obama calls 'the stay-at-home moms') is innate - the best or only model of motherhood. I want my daughters to have a choice as to what's best for them and their families" (2006: 343). This celebration of women was consistent with the Democratic Party's ethos in the years preceding the 2008 presidential election, which stood in stark contrast with the backlash women had suffered after 9/11 when female independence and career ambitions were repudiated (Faludi, 2007 : 116-145).

So, I would contend that the Democratic Party brought the 'War on Women' to a halt and participated in the restoration of feminism. It was particularly conspicuous after Bush's reelection in 2004 when the Democrats started campaigning for Hillary Clinton who eventually became the first woman running for president. Besides, The 'War on 
Women' seemed to recede even more as the President's popularity dramatically dropped after the mishandling of Hurricane Katrina in 2005 and the growing chaos in Iraq which aroused such protest at home that it gave a landslide victory to the Democratic party in the 2006 midterm elections, causing Donald Rumsfeld to resign from Secretary of Defense. The Republican Party lost both the House of Representatives and the Senate, which meant that passing conservative bills - including those which directly or indirectly targeted women - would prove far more difficult for the executive branch which now had to contend with a vast liberal opposition in Congress acting on progressive ideas. To top it all, the Democratic party chose Nancy Pelosi - an openly pro-choice politician - to preside over the House, thereby making her the nation's firstfemale House speaker. This feminist revival was confirmed by a 2007 Gallup poll which stated that eighty-eight percent of Americans were ready to vote for a 'well-qualified woman for president' (Kohut, 2007), underscoring that gender was no longer an impediment for candidates running for president.

It is worth noting that, from 2004 onwards, television series embraced this liberal turn and started featuring female characters as US Presidents and paved the way for Hillary Clinton's potential candidacy. We may think of Laura Roslin in Battlestar Galactica (Sci Fi, 2004-9) but also Mackenzie Allen in the short-lived yet illuminating Commander in Chief (ABC, 2005-6), although both of them accede to presidency as a result of calamity. Commander in Chief stars Geena Davis as Mackenzie Allen, the first female Vice President who becomes the first female President of the United States after the sudden death of the incumbent Republican president. This liberal-oriented series, which tries to be neutral by labeling Allen an independent and portraying both the Democratic and Republican parties as cynical and only interested in their own partisan agendas, was seen as 'Hillary's Infomercial' by conservative pundits who argued that its political bias was 'comically unsubtle' (Johnson, 2005). Regardless of the political dimension of the show and whether or not it served as a vehicle for Clinton's candidacy, Commander in Chief delivers a message that was not consensual yet: a woman could be president and she could even be better at the job than a man. Indeed, Mackenzie Allen successfully manages all kinds of crises in her own 'feminine' way. Although the show reaffirms some gendered conceptions of femininity (e.g. Allen is opposed to unnecessary violence, torture and impulsive action, and defends women's rights), it presents them in a positive light, turning them into strengths whereas the Bush administration considered them weaknesses.

In the wake of these series, 24's seventh season introduces Allison Taylor as the new US President. Unlike Allen, Taylor is supposed to be a Republican president despite her progressive politics and, more important, she was properly elected by the American people (see 24 : Redemption which depicts the inauguration ceremony), which makes her a legitimate president. Still, like Allen, Taylor was also described as a Clinton-ish character by the media, some critics arguing that she was "the best fictional Hillary Clinton of all time" (VanDerVerff, 2015), implying that 24 had become a Democratic vehicle $^{3}$. This was obviously quite ironic for a series that had always been criticised, or praised, for its close relationship with the Bush administration. Taylor was the first Republican president in the show to be depicted in such a positive light, at least in season 7. Commander in Chief. She has a strong, manly temper which somehow breaks with the 
way femininity is usually defined. Mackenzie Allen was depicted in trendy clothes fitting her curves and with glossy lips and a little make-up - we even see her wearing a fancy dress for a gala celebrating the visit of the Russian President [S01xE04]. Contrariwise, Taylor is always wearing a strict, high-necked dress and has a rather masculine look. The masculine portrayal of Taylor offers interesting gender reversals as she is also endowed with psychological characteristics that are traditionally seen as masculine. For example, we learn from the beginning that Taylor's son committed suicide, although we come to find out that he was actually murdered, but she handles it with detachment, almost callousness while her husband Henry is the one who is hysterical, much in the vein of Martha Logan, and continually laments the death of his son and keeps investigating what he thinks is a conspiracy. When Taylor's Chief of Staff shares his concern with Taylor about her husband's unrest, she says, 'He lost a son.' Then, Ethan answers, "So did you. And you haven't let your loss interfere with your job. " [S07xE01] Henry is therefore turned into the 'feminine' figure of the couple, alongside his being the First Gentleman, which is reinforced later on when he is kidnapped by terrorists who threaten to kill him if Taylor carries on with the invasion of Sangala. Suddenly, the traditional damsel in distress becomes a First Gentleman in distress whose life depends on his wife's decision and on Jack's intervention [S07xE08]. And when Henry is freed by Jack after being shot, Taylor indulges in masculine swearing when she says, "Whatever it takes, I want that son of a bitch [Colonel Dubaku] found" [S07xE09].

30 So, from season 7 onwards, as 24 takes a liberal turn, female characters become ubiquitous and their roles are redefined. Jean-Baptiste Jeangène Vilmer notes that "at some point [in season 8], global peace and security rest in feminine hands: President Taylor, Dalia, who has replaced her murdered husband President Hassan, and Chloe who has been promoted as CTU's acting director" (2012: 146). Later, in season 9, the Islamic terrorist threatening London is a woman, Margot Al-Harazi, who seeks to avenge the death of her husband killed by a US drone attack. For the first time in 24, the main villain is a woman and her gender in no way undermines her determination or maleficence. Moreover, prior to season seven, Jack had never had a female team partner, except Nina Myers who turned out to be a mole, implying that women could not physically fight terrorism and that their war effort was restricted to gathering intelligence or providing technological support to the male heroes. But, in the last seasons, we discover two prominent action heroines, FBI agent Renee Walker (season 7-8) and CIA agent Kate Morgan (season 9), who team up with Jack and offer a brand new representation of women in the show. These female protagonists are clever and physically strong and appear as Jack's mirror images. Like Jack, they disobey orders from their hierarchy, they have a crucial sense of foretelling what the terrorists' next move is going to be and yet their voices are never given consideration, and, most importantly, they make it through the worst tortures virtually unaffected (see Kate in S09xE06). Still, one could argue that the series' switch to philogyny is incomplete because it is somewhat undermined by the fact that female characters need to resemble Jack and fall into line with his alpha-male, violent behaviour to be efficient agents. Put differently, since Jack's agency and competence seem to lie in his masculinity, so his female coworkers need to act like him, like men, if they want to defeat the terrorists.

31 All in all, their involvement is cardinal and they contribute to saving the day. 24's action heroines were so popular that the media reported that a potential tenth season might be centred on Kate's character, with Jack exiting the show (Mitovitch, 2014). 
However, the spin-off 24: Legacy (Fox, 2017) which aired in 2017 revolves around another action man, ex-Army Ranger Eric Carter, whose most notable difference with Jack lies in his being African American.

In conclusion, 24 elicits a form of misogyny in its audience first and foremost because of its portrayal of women. Be they submissive, idiotic, traitorous or insane, the women of 24 cannot be trusted to fight the War on Terror which, in the series, remains a man's job. "Everybody on the show is duplicitous, not just the female characters," co-creator Robert Cochran asserted, "they are not helpless victims or impossible noble, any more than the men are." (McPherson, 2007 : 189) Still, in spite of this attempt at disclaiming the accusations of misogyny that were made against the show during its run, it is hard not to see that the women of 24 suffer a particularly negative treatment, at the very least in the first seasons where no female character can compete with alpha male Jack Bauer's heroism.

This has obviously much to do with the show's generic hybridity as it recycles elements of the action-adventure series and the soap opera, two genres which usually provide stereotypical female characters, and with the fact that it was broadcast by conservative network Fox. Because it attempted to restore America's masculinity after the 9/11 attacks, 24 gave a vision of the War on Terror which was generally in tune with the ideology of the Bush administration. Like the President whom the TIME dubbed a 'Lone Ranger', Bauer reenacted the (conservative) Western imagery of the cowboy, an imagery that was called on by popular culture to provide a disoriented people with a sense of order.

In its later seasons, 24 took a more liberal turn. Not only did it query the rationale of the War on Terror and the use of torture, but it also departed from its early misogynistic ideology. I suggested that it resulted from the departure of conservative co-creator Joel Surnow, whose political influence on the show was substantial, but also from the political context itself. Bush's second term was marked by the precipitous decline in his popularity and power and the rise of new progressive forces which, as early as 2004, started pushing for Hillary Clinton's candidacy. The conservative 'War on Women', so salient during the first term of President Bush, then came to halt. 24 mirrored those evolutions by offering renewed, more positive female characters: women could now be highly skilled agents, Senior Advisor to the President (Karen Hayes in season 6), or even the President of the United States. Even though 24 kept on introducing a few very irritating female characters in its last seasons such as Dana Walsh, yet they were at least compensated by an array of new strong, heroic counterparts, which made the show look almost philogynist.

The liberal turn in the last seasons of 24 has since been observed in other terrorism shows like Homeland (Showtime, 2011-), a series partly produced and written by 24 veterans. The main protagonist is not a diehard male agent but an unstable female agent, namely Carrie Mathison. She subverts some of the archetypes at work mainly in the first seasons of 24. True, she suffers from bipolar disorder and is often seen going through severe breakdowns, which echoes 24's mad women like Maya, but her condition is not depicted as a weakness or a 'female malady' preventing her from defeating the terrorists. On the contrary, Homeland presents Carrie's (feminine) 
disorder as genius and her excessive paranoia as intuition which enable her to excel at undoing terrorist threats: "[The series] portrays an action woman whose gender identity helps to solve the contradiction that exists between agency and femininity, between public and private spheres, because Carrie's femininity which is essentialised as pathological and compulsive is pointed out as the reason of her victory over terrorism." (Courcoux, 2016: 86) In the series, the 'narrative distracters' are Carrie's male superiors who refuse to believe her because of her mental illness and, possibly, gender. As for the traitors, they are also men for the majority, from Sergeant Nicholas Brody (season 1) to the US ambassador's husband Danny Doyle (season 4) and CIA's director Dar Adal (season 6).

By and large, Homeland participates in the recent upsurge of TV series featuring female heroines (see Madam Secretary, State of Affairs, etc.) who take over previously maledominated high positions. In so doing, they portray a post-'War on Women' America and show that women are as competent as or actually more competent than men. This was already what 24 sought to demonstrate with the example of President Taylor which could have been seen as prescient had Hillary Clinton been elected President in 2016. Nevertheless, the election of Donald Trump has aroused fear amongst feminist groups that a new war might be declared on women. He has cut off funding to a large number of federal agencies, including programmes supporting women's rights and guaranteeing gender equality, and shown fierce opposition to abortion. He has made it clear his intent to overturn or at least undermine the 1973 Roe v. Wade decision by appointing very conservative justices in federal and state Supreme Courts. Still, given Hollywood's massive support to Hillary Clinton during the last presidential campaign, it will very unlikely espouse the President's reactionary agenda and turn back the clock on women.

\section{BIBLIOGRAPHY}

AMNESTY INTERNATIONAL (2004), Casualties of War. Women's Bodies, Women's Lives, Amnesty International Publications.

BRADY Sara (2012), Performance, Politics and the War on Terror, London, Palgrave Macmillan.

BREW Simon (2009), 'Kim Bauer : television's dumbest character'. Available at : http://

www.denofgeek.com/tv/20024/kim-bauer-televisions-dumbest-character [accessed 10 June 2016]

courcoux Charles-Antoine (2015), «À l'Ouest, quelque chose de nouveau ? Féminité et sexualité dans les séries américaines contemporaines ", in Laetitia BISCARRAT et Gwénaëlle LE GRAS (ed.),

Genre en séries, $\mathrm{n}^{\circ}$ 2, p. 73-97.

CUPP Sarah Elizabeth and Brett Joshpe (2008), Why You're Wrong about the Right. Behind the Myths :

The Surprising Truth about Conservatives, New York, Threshold Editions. 
DODWELL Karen (2004), 'From the Center : The Cowboy Myth, George W. Bush, and the War with Iraq'. Available at : http://www.americanpopularculture.com/archive/politics/ cowboy_myth.htm [accessed 14 April 2017] FALUDI Susan (2007), The Terror Dream, London, Atlantic Books.

FINEMAN Howard (2001), 'Newsweek Exclusive Interview : President George W. Bush and Laura Bush'. Available at : https://www.thefreelibrary.com/

Newsweek+Exclusive+Interview\%3A+President+George+W.+Bush+and+Laura+Bush.-a080278143 [accessed 10 April 2017]

FINLAY Barbara (2006), George W. Bush and the War on Women, New York, Zed Books.

HERMES Joke (2007), 'Father Knows Best ? The Post-Feminist Male and Parenting in 24', in Steven PEACOCK (ed.) Reading 24, TV Against the Clock, London, I.B. Tauris, p. 163-172.

GILBERT Sandra and Susan GUBAR (1979), The Mad Woman in the Attic: The Woman Writer and the Nineteenth-Century Literary Imagination, New Haven, Yale University Press.

GUTHRIE Marisa and Lacey ROSE (2011), 'Testosterone TV : What Shows Are Most Watched By Men ?'. Available at : http://www.hollywoodreporter.com/news/television-shows-menwatch-222356 [accessed 7 April 2017]

JoHnson Ben (2005), ‘Commander in Chief : Hillary's Infomercial'. Available at : http:// archive.frontpagemag.com/readArticle.aspx?ARTID=7109 [accessed 10 June 2016]

KонUT Andrew (2007), 'Are Americans Ready to Elect a Female President?' Available at : http:// www.pewresearch.org/2007/05/09/are-americans-ready-to-elect-a-female-president/ [accessed 11 June 2016]

MAYER Jane (2007), 'Whatever it takes : The politics of the man behind 24', The New Yorker. MCCABE Janet (2007), 'Damsels in Distress : Female Narrative Authority and Knowledge in 24', in Steven PEACOCK (ed.), Reading 24, TV Against the Clock, London, I.B. Tauris, p. 149-162.

MCPHERSON Janet (2007), 'Techno-Soap : 24, Masculinity and Hybrid Forms', in Steven PEACOCK (ed.), Reading 24, TV Against the Clock, London, I.B. Tauris, p. 173-190.

MiтоviтcH Matt Webb (2014), '24 Boss : Time Jump Is Coming - Plus, Might Jack Pass the Baton to Kate ?' Available at : http://tvline.com/2014/06/13/24-live-another-day-time-jump-kate-replacejack/ [accessed 20 June 2016]

MUMFORD Laura Stempel (1995), Love and Ideology in the Afternoon : Soap Opera, Women and Television Genre, Bloomington, Indiana University Press.

PICHARD Alexis (2016), 'La septième saison de 24 heures chrono : illusion d'un tournant moral et éthique ?', in Marjolaine воUтEт (ed.), TV/Series, n 9. DOI : 10.4000/tvseries.1268

PICKUP Oliver (2010), 'George W. Bush is the most unpopular living U.S. president, claims survey'. Available at : http://www.dailymail.co.uk/news/article-1336439/George-W-Bush-unpopularliving-US-president.html [accessed 10 November 2015] SHOWALTER Elaine (1985), The Female Malady : women, madness, and English culture, 1830-1980, New York, Pantheon Books.

SNYDER R. Claire (2007), 'The Allure of Authoritarianism : Bush Administration Ideology and the Reconsideration of Patriarchy', in Michaele L. FERGUSON and Lori LO MARSO (eds.), W Stands for 
Women : How the George W. Bush Presidency Shaped a New Politics of Gender, Durham, Duke University Press, p. 17-40.

WESTWELL Guy (2014), Parallel Lines, London, Wallflower Press.

\section{NOTES}

1. The cited comments can be found at : http://www.ign.com/boards/threads/dana-walsh-worstside-plot-ever.189451514/ [accessed 15 October 2015] ; the reaction cited in the title of the article is the topic of a discussion that can be consulted at: http://www.gamefaqs.com/boards/225television-broadcast-tv/62461068 [accessed 11 June 2016)]

2. The strong father/revenger motif can be seen in Man on Fire (Scott, 2004), War of the Worlds (Spielberg, 2005), Firewall (Loncraine, 2006), Die Hard : Live Free of Die Hard (Wiseman, 2007), and in the Taken trilogy (Morel, Megaton, 2008-2015).

3. Season 7 was supposed to air in January 2008, before the presidential election, but was postponed to the following year because of the Writers' Strike that burst out in November 2007. So, Taylor would have been president while Clinton was campaigning for the Democratic Party nomination. It is obviously impossible to assume that the portrayal of a female president in 24 could have changed the outcome of both the primary and presidential elections.

\section{ABSTRACTS}

This article investigates the misogyny at work in Fox's hit series 24 . Filled with stereotyped female characters, 24 seems to provide a univocal portrayal of women which spurs the viewers' misogyny. Still, 24's defiance towards women needs to be understood in the light of a particular context, the post-9/11 years, during which the Bush administration and conservative pundits targeted women as responsible for the 2001 terrorist attacks and fought a political and cultural 'War on Women'. Therefore, we may postulate that with the election of Barack Obama in 2008, America took a liberal turn which impacted television series, and 24 in particular. This may account for the more progressive later seasons of the show where female characters are no longer ascribed to secondary roles but become action heroines, acting directors of intelligence agencies and, for one of them, elected Commander in Chief.

Cet article analyse la misogynie à l'œuvre dans 24 heures chrono. Émaillée de personnages féminins stéréotypés, la série semble dresser un portrait des femmes univoque attisant les penchants misogynes des spectateurs. Cette tendance doit néanmoins être appréhendée à l'aune d'un contexte particulier, celui de l'après-11 Septembre. Durant cette période, l'administration Bush, assistée par de nombreux idéologues conservateurs, mena une "guerre contre les femmes » aussi bien politique que culturelle. L'élection du démocrate Barack Obama en 2008 vint temporairement mettre un terme à cette guerre et inaugura une période de renouveau des représentations genrées. Cela pourrait expliquer le virage progressiste opéré par 24 heures chrono lors de ses dernières saisons: jadis cantonnées à des rôles caricaturaux et secondaires, les femmes devinrent agent fédéral, directrice des agences gouvernementales, ou encore présidente des États-Unis. 
INDEX

Mots-clés: femmes, 24 heures chrono, misogynie, George W. Bush, guerre contre le terrorisme, guerre contre les femmes, Amérique de l'après-11 septembre

Keywords: women, 24 (TV series), misogyny, George W. Bush, war on terror, war on women, Post-9/11 America 